\title{
Clinical center overhaul: Common cents?
}

Advice columnist Ann Landers and common sense often dictate: "If it ain't broke, don't fix it." But a proposal under consideration at the US National Institutes of Health (NIH) has researchers and administrators wondering just what the problem is. At issue is an effort spearheaded by Health and Human Services Director (HHS) Donna Shalala to consider the feasibility of contracting out the services of the $\mathrm{NIH}$ Clinical Center. The Clinical Center, which houses 40 percent of all subjects involved in clinical research throughout the US, is the testing ground for experimental drugs and treatments not readily available at other hospitals and research centers.

"With HMOs becoming more prevalent, it is becoming progressively more difficult for university-based hospitals to recruit patients for clinical research," says John Gallin, director of the NIH Clinical Center. "That makes the Clinical Center more of a unique entity. And it makes me very nervous of the prospect of the wholesale contracting of the center."

Shalala has asked Helen Smits, of the US Health Care Finance Administration to over-see the review of a series of options on how to improve the operation of the facil-

ity. The review apparently stems from VicePresident Al Gore's efforts to cut government waste in a programme known as "Reinventing Government II" (REGO II). Smits has met with NIH Director Harold Varmus, institute directors, senior management officials and union representatives. She will assemble a Technical Advisory Group that will be composed of individuals from inside and outside of the $\mathrm{NIH}$ intramural programme.

According to Gallin, Smits has an open mind and is not committed to any specific proposal. Within two to three months, Smits and her committee are expected to report to Shalala on what specific plans are worth pursuing, and within 7 to 9 months, she hopes to begin implementing a plan. Although the idea of turning over all operations of the center, including research, seems unlikely, the committee will review the possibilities of contracting out custo- dial, procurement, and personnel services.

Gallin says that political pressures may give rise to a perceived problem with the Clinical Center. "There is pressure to reduce the federal work force," says Gallin. "But replacing government employees with contract workers won't necessarily save money." He says that by shifting many inpatient services to outpatient, the Clinical Center has already reduced its operating budget by $\$ 10$ million dollars. "I think we will show the secretary that we have an efficiently run facility and that it would cost more to run it under contract." Gallin says the thrust under the current administration is to reduce the total number of federal employees. "It's easier to get rid of a contractor than a federal employee," he says. Privatization could have a broad impact at NIH if ousted employees bump less senior employees from other positions. But it is not yet clear which employees will be affected.

In a related development, the Inspector General's Office at HHS has recently reviewed the cost of conducting clinical trials at the Clinical Center and has put forth several controversial recommendations, including a requirement that participants in clinical trials pay for services rendered. Currently, all volunteers in trials at the Clinical Center are treated free of charge.

"Requiring research subjects to pay for services may lead to the selection of a skewed population - those that have medical insurance," says Gallin. One recommendation calls for requiring payment from control patients only. But in a double-blind trial, neither researchers nor patients know who the control subjects are. Attempts to unmask the study could cast doubt on study results. In addition, says Gallin, the money saved by requiring third-party payment would be minimal.

"The Clinical Center represents an opportunity to conduct clinical studies not possible anywhere else," says Gallin. "Why would you want to mess with that?"

NANCY TOUCHETTE Baltimore, Maryland
DID YOU KNOW ...?

Italian medical association to curb assisted-reproduction practices Just a coincidence? Pope John Paul II's Evangelium Vitae, lambasting contraception, medically assisted procreation and experiments on human embryos, was released at the same time as the Italian Council of Doctors' (the official medical association of Italy) decision to regulate medically assisted procreation.

Italian doctors are now no longer allowed to provide in vitro fertilization for women over fifty and single women. They can no longer bring frozen embryos into the world when one parent is deceased. Using new reproductive technologies to weed out certain traits for racial or elite purposes or to turn a profit is also strictly out of the question.

All of the above had become quite commonplace in Italy. Indeed some doctors working at private clinics eagerly sought media coverage for their medical feats. However, some doctors, scientists and politicians had already begun to pressure Parliament to pass legislation.

The doctor's council (300,000-strong) has decided to take the first step. Offending doctors will be liable for penalties ranging from disciplinary action to debarment. CATHERINE TASTEMAIN

Paris

\section{Changes to European patent rules abandoned}

A move to harmonize biotechnology patent rules in all of Europe failed in early March when the European Parliament voted by 240 votes to 188 to abandon the plan. The vote was a victory for environmental groups and other lobbyists opposed to the patenting of human, animal and plant genes.

The Directive on the Legal Protection of Biotechnological Inventions was intended to promote the development of European biotechnology. But many in the biotechnology industry were relieved it was not passed because the directive had been so heavily watered down in an attempt to win its approval. In particular, later drafts of the directive (six years in the making) tried to prohibit the patenting of genes in the human body while allowing patents on synthetic versions of the same genes.

Companies will still be able to get Europewide protection from the European Patent Office in Munich, but disputes will have to be dealt with in the country in which they arise.

NuALA MORAN London 